Please do not remove this page

RMIT

UNIVERSITY

\title{
Developing an uncertainty analysis model for off-site building production
}

Arashpour, Mehrdad; Wakefield, Ronald

https://researchrepository.rmit.edu.au/esploro/outputs/9921860036801341/filesAndLinks?institution=61RMIT_INST\&index=null

Arashpour, M., \& Wakefield, R. (2015). Developing an uncertainty analysis model for off-site building production. Proceedings of the Eighth International Structural Engineering and Construction Conference (ISEC-08), 1121-1125. https://doi.org/10.14455/ISEC.res.2015.7

Document Version: Published Version

Published Version: https://doi.org/10.14455/ISEC.res.2015.7

Repository homepage: https://researchrepository.rmit.edu.au

Copyright (c) 2015 ISEC Press

Downloaded On 2023/04/26 11:03:47 +1000

Please do not remove this page 
Thank you for downloading this document from the RMIT Research Repository.

The RMIT Research Repository is an open access database showcasing the research outputs of RMIT University researchers.

RMIT Research Repository: http://researchbank.rmit.edu.au/

\section{Citation:}

Arashpour, M and Wakefield, R 2015, 'Developing an uncertainty analysis model for off-site building production', in Saha, S., Zhang, Y., Yazdani, S., and Singh, A (ed.) Proceedings of the Eighth International Structural Engineering and Construction Conference (ISEC-08), Fargo, United States, 23-28 November 2015, pp. 1121-1125.

See this record in the RMIT Research Repository at: https://researchbank.rmit.edu.au/view/rmit:35833

Version: Published Version

Copyright Statement: @ 2015 ISEC Press

Link to Published Version:

http://dx.doi.org/10.14455/ISEC.res.2015.7

\section{PLEASE DO NOT REMOVE THIS PAGE}




\title{
DEVELOPING AN UNCERTAINTY ANALYSIS MODEL FOR OFF-SITE BUILDING PRODUCTION
}

\author{
MEHRDAD ARASHPOUR ${ }^{1}$ and RON WAKEFIELD ${ }^{2}$ \\ ${ }^{1,2}$ School of Property, Construction and Project Management,RMIT University, Melbourne, \\ Australia
}

\begin{abstract}
The hybrid use of off-site and on-site processes in construction projects has increased significantly over the past decade. The analysis and management of uncertainty in hybrid projects is not a trivial task as workflow variability in off-site and on-site operations can interact and amplify one another. The aim of this paper is to analyze various drivers of uncertainty such as high levels of project complexity, risk seeking behaviors, unavailability of resources, and combined variability in hybrid projects. Production data of two Australian construction companies were collected and utilized in modeling uncertainty. Findings show the significant effect of uncertainty drivers on project plan reliability and the necessity of an adequate uncertainty analysis and management in hybrid projects. The results of this study enhance the knowledge about management of hybrid projects and have the potential to improve the way construction companies deal with uncertainty in project environments.
\end{abstract}

Keywords: Construction management, Delays and rework, Hybrid projects, Plan reliability, Simulation and optimization, Site built processes, Workflow analysis

\section{INTRODUCTION}

Off-site production offers important benefits to construction projects. These benefits include but are not limited to reduced direct cost of labor and building components (Arashpour, Shabanikia et al. 2012), better quality of production in a controlled environment (Chan, Yuen et al. 2015), and lower rates of worksite accidents (Blismas, Wakefield et al. 2010). Off-site construction, however, can cause complexity in management of projects especially when paired with on-site construction activities. So called hybrid projects are prone to deviations from project plans (Yoon and Ventura 2002), increased uncertainty (De Meyer, Loch et al. 2002), and resource constraints (Fang, Marle et al. 2013).

Increasingly construction companies use both off-site and site-built elements in their projects and a holistic analysis of uncertainty is required to increase project plan reliability in hybrid projects (Arashpour, Wakefield et al. 2014a). However, methodical research on this matter is sparse in the construction literature (Rashki, Miri et al. 2014). In order to bridge this gap, this study uses an empirical research approach to analyze the impact of uncertainty and complexity on hybrid construction projects. For this purpose, off-site and on-site construction activities in two large Australian construction companies were investigated. Research findings show meaningful relationships 
between project plan reliability $(P P R)$ and characteristics of hybrid projects, namely level of project complexity, risk seeking attitudes of project participants, resource constraints, and combined uncertainty in off-site and on-site construction activities.

\section{COMPLEX AND UNCERTAIN CONTEXT OF HYBRID CONSTRUCTION PROJECTS}

Previous research has shown that project size and elements of context increase project complexity results in a decreasing level of project plan reliability (Saha, Hardie et al. 2013, Arashpour and Arashpour 2015a). In order to analyze the impact of project size on level of project plan reliability (PPR), actual data from the two hybrid construction projects were utilized in 20 simulation experiments with various levels of work quantities. As opposed to the traditional planning and control techniques such as PERT, normal/Beta distributions were not the sole representatives of on-site and off-site activities. Therefore, randomness in activity durations and rework processes was reflected by fitting the optimum probability distributions to the collected real-world data. The goodness of fit was tested using Chi-Square test, Anderson-Darling (A-D) test, and Kolmogorov-Smirnov (K-S) test. Discrete event simulation (DES) experiments were run for 100 times to achieve a confidence level of 99\% with all standard errors within $0.5 \%$. Results of simulation experiments have been illustrated in Figure 1.

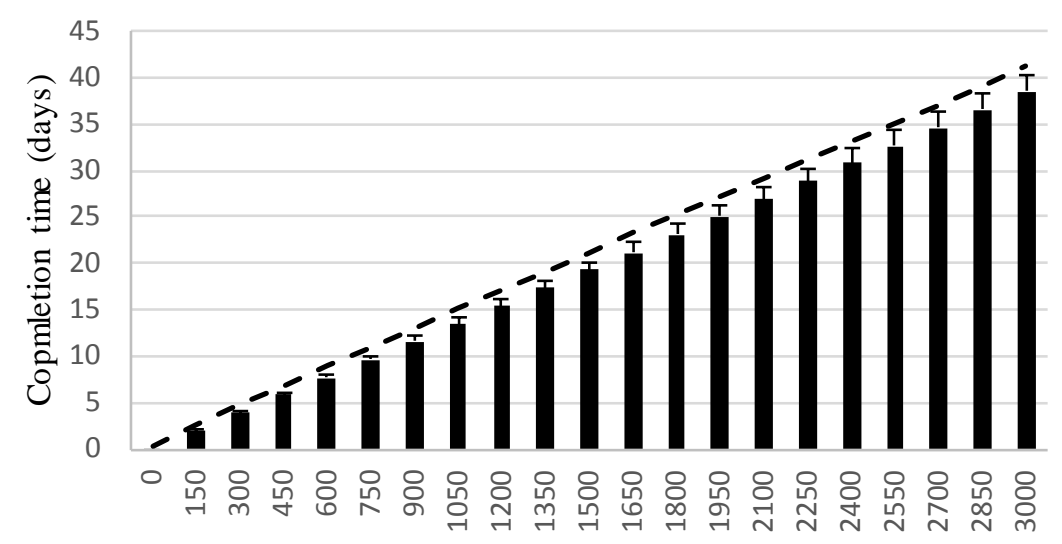

Work quantities (hours)

Time estimates in project plan _ - - Reliable project duration

Figure 1. Impact of work quantities and project complexity on completion times

As can be seen in Fig.2, increasing project work quantities and complexity result in a linear increase in completion times. Understandably, dedicating more resources to project will not necessarily change the situation as there are many activities with fixedtime durations, such as pouring and curing concrete, that cannot be crashed beyond a certain point. That is why reliable completion time (dashed line in Fig. 2) is always longer than estimated completion time in project plans (vertical bars). More importantly, time gap between the two is more when large work quantities are involved (complex projects). This is in line with findings in our site observations in the two 
construction companies where growth in hybrid project size and work quantities intensified pair and group interconnection of tasks within and between groups of on-site and off-site activities, resulting in lengthened completion times and deviations from project plans. These findings are consistent with those of Saha and Hardie (2008), and Arashpour, Wakefield et al. (2013b).

\section{LEVEL OF RESOURCE AVAILABILITY IN HYBRID CONSTRUCTION PROJECTS}

Resource constraints have a significant impact on project duration (Arashpour, Wakefield et al. 2015b). In hybrid projects, there are different constraints on project resources in on-site and off-site environments. In off-site construction, equipment and materials are the critical resources and labors (machine operators) are often dedicated resources to the production side of hybrid projects (Arashpour, Wakefield et al. 2014b). In on-site project activities, however, subcontractors and skilled labors are critical resources for timely completions (Loosemore and Andonakis 2007, Tam, Shen et al. 2011, Manu, Ankrah et al. 2013). Interestingly, even within a construction company with several running projects, there may be competition among building supervisors to attract on-demand resources, such as skilled carpenters, to their own project (Laslo and Goldberg 2008).

The observations in the two companies revealed the same pattern for critical resources in off-site and on-site project activities. Figure 2 illustrates the actual completion times associated with different levels of resource availability in hybrid projects.

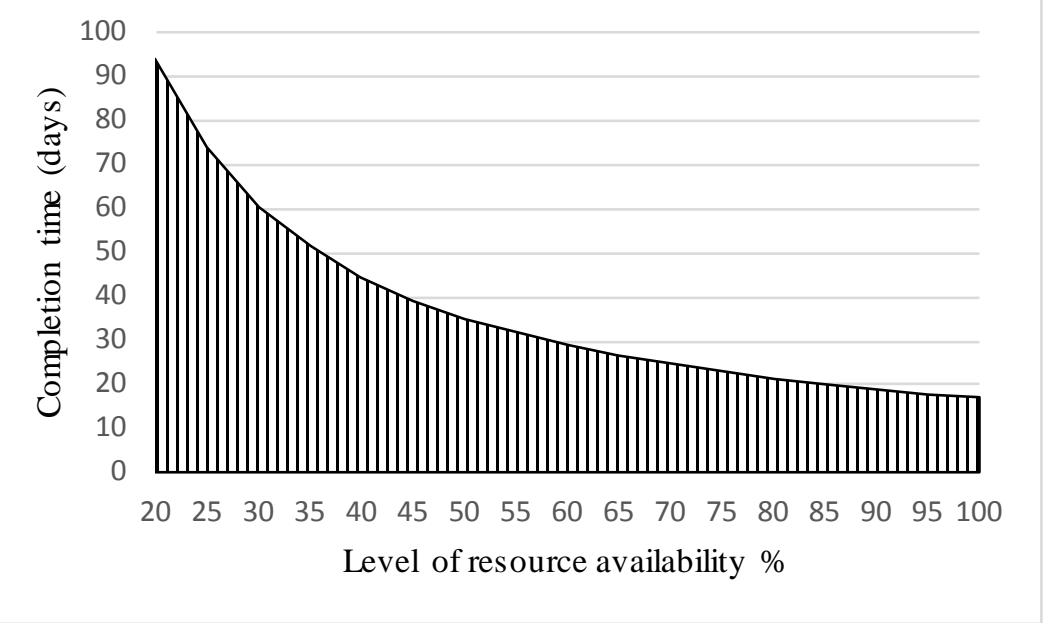

Figure 2. Impact of resource availability on completion times

The reason behind decreased completion time, and thus reduced risk of delays with regard to the project plan, is that availability of required resources increases the workflow continuity in hybrid projects. In fact, relaxation of resource constraints can reduce risks of both late completions and low plan reliability in hybrid projects. This is 
consistent with findings of Ahern, Leavy et al. (2014) and Arashpour, Wakefield et al. (2015c).

\section{CONCLUSION}

Prior work has documented the effects of uncertainty on off-site construction activities (Saha 2008, Arashpour, Wakefield et al. 2013c). However, these studies have not focused on hybrid construction projects where on-site and off-site activities are concurrently in progress. In this study, two large Australian commercial builders were chosen and their production processes were investigated.

Results of the empirical analysis show that uncertainty in hybrid projects is mainly driven by large work quantities, risk seeking attitudes of project participants, unavailability of resources, and variability of workflow in off-site and on-site activities. These findings extend those of Arashpour, Wakefield et al. (2013a), confirming that uncertainty is an important characteristic of hybrid construction projects and needs to be analyzed and managed properly.

This work contributes to the body of knowledge in the field of construction engineering and management by analyzing major contributors to uncertainty in hybrid projects. The findings have great potential to improve performance and productivity in hybrid projects and assist construction companies to find the most cost-effective way of managing their off-site and on-site project activities.

\section{References}

Ahern, T., B. Leavy and P. J. Byrne (2014). "Complex project management as complex problem solving: A distributed knowledge management perspective." International Journal of Project Management 32(8): 1371-1381.

Arashpour, M. and M. Arashpour (2015a). "Analysis of Workflow Variability and Its Impacts on Productivity and Performance in Construction of Multistory Buildings." Journal of Management in Engineering: DOI: 10.1061/(ASCE)ME.1943-5479.0000363.

Arashpour, M., M. Shabanikia and M. Arashpour (2012). "Valuing the contribution of knowledge-oriented workers to projects: a merit based approach in the construction industry." Australasian Journal of Construction Economics and Building 12(4): 1- 12.

Arashpour, M., R. Wakefield and N. Blismas (2013a). Role of simulation in construction processes-harmony in capturing resources. Research, Development and Practice in Structural Engineering and Construction (ASEA-SEC), Research Publishing Services (RPS).

Arashpour, M., R. Wakefield and N. Blismas (2013b). Improving construction productivity: implications of even flow production principles. CIB World Building Congress 2013: Construction and Society, Queensland University of Technology.

Arashpour, M., R. Wakefield, N. Blismas and E. W. M. Lee (2013c). "A new approach for modelling variability in residential construction projects." Australasian Journal of Construction Economics and Building 13(2): 83-92.

Arashpour, M., R. Wakefield, N. Blismas and E. W. M. Lee (2014a). "Analysis of disruptions caused by construction field rework on productivity in residential projects." Journal of Construction Engineering and Management 140(2): 1-12.

Arashpour, M., R. Wakefield, N. Blismas and E. W. M. Lee (2014b). "Framework for improving workflow stability: Deployment of optimized capacity buffers in a synchronized construction production." Canadian Journal of Civil Engineering 41(12): 995-1004. 
Arashpour, M., R. Wakefield, N. Blismas and T. Maqsood (2015b). "Autonomous production tracking for augmenting output in off-site construction." Automation in Construction 53(0): 13-21.

Arashpour, M., R. Wakefield, N. Blismas and J. Minas (2015c). "Optimization of process integration and multi-skilled resource utilization in off-site construction." Automation in Construction 50(1): 72-80.

Blismas, N., R. Wakefield and B. Hauser (2010). "Concrete prefabricated housing via advances in systems technologies: Development of a technology roadmap." Engineering, Construction and Architectural Management 17(1): 99-110.

Chan, R. W. K., J. K. K. Yuen, E. W. M. Lee and M. Arashpour (2015). "Application of Nonlinear-Autoregressive-Exogenous model to predict the hysteretic behaviour of passive control systems." Engineering Structures 85(1): 1-10.

De Meyer, A., C. H. Loch and M. T. Pich (2002). "Managing project uncertainty: From variation to chaos." MIT Sloan Management Review 43(2): 60-67.

Fang, C., F. Marle, M. Xie and E. Zio (2013). "An integrated framework for risk response planning under resource constraints in large engineering projects." IEEE Transactions on Engineering Management 60(3): 627-639.

Laslo, Z. and A. I. Goldberg (2008). "Resource allocation under uncertainty in a multiproject matrix environment: Is organizational conflict inevitable?" International Journal of Project Management 26(8): 773-788.

Loosemore, M. and N. Andonakis (2007). "Barriers to implementing OHS reforms - The experiences of small subcontractors in the Australian Construction Industry." International Journal of Project Management 25(6): 579-588.

Manu, P., N. Ankrah, D. Proverbs and S. Suresh (2013). "Mitigating the health and safety influence of subcontracting in construction: The approach of main contractors." International Journal of Project Management 31(7): 1017-1026.

Rashki, M., M. Miri and M. A. Moghaddam (2014). "A simulation-based method for reliability based design optimization problems with highly nonlinear constraints." Automation in Construction 47(0): 24-36.

Saha, S., M. Hardie, X. H. Jin and S. Braid (2013). Adoption of building information modelling as a project management tool. 7th International Structural Engineering and Construction Conference: New Developments in Structural Engineering and Construction, ISEC 2013, Research Publishing Services.

Saha, S. K. (2008). The effects of experience \& interruption in a construction inspection task. 11th East Asia-Pacific Conference on Structural Engineering and Construction, EASEC11, Taipei.

Saha, S. K. and M. P. Hardie (2008). Construction error and optimal inspection rate. 4th International Structural Engineering and Construction Conference, ISEC-4 - Innovations in Structural Engineering and Construction, Melbourne, VIC.

Tam, V. W. Y., L. Y. Shen and J. S. Y. Kong (2011). "Impacts of multi-layer chain subcontracting on project management performance." International Journal of Project Management 29(1): 108-116.

Yoon, S. H. and J. A. Ventura (2002). "Minimizing the mean weighted absolute deviation from due dates in lot-streaming flow shop scheduling." Computers and Operations Research 29(10): 1301-1315. 